\title{
Polymorphism scanning of HSP90AB1 gene in local Friesian Holstein as molecular marker for heat stress resistance
}

\author{
Sigit Prastowo ${ }^{*}$, M. Mumtaz Adzdzakiy ${ }^{2}$, Rebecca Vanessa $^{3}$, Galih Pambuko ${ }^{1}$, \\ Purwadi $^{4}$, Ari Susilowati ${ }^{3}$, Sutarno ${ }^{2}$ \\ ${ }^{1}$ Animal Science Department, Faculty of Agriculture, Universitas Sebelas Maret, Surakarta, Indonesia \\ ${ }^{2}$ Department of Biology, Faculty of Mathematics and Natural Sciences, Universitas Sebelas Maret, \\ Surakarta, Indonesia \\ ${ }^{3}$ Graduate School of Bioscience, Faculty of Mathematics and Natural Sciences, Universitas Sebelas \\ Maret, Surakarta, Indonesia \\ ${ }^{4}$ Faculty of Animal Husbandry, Universitas Boyolali, Boyolali, Indonesia
}

\begin{abstract}
Heat stress poses major problem in dairy cattle in term of reproduction and milk yield, especially in humid tropical climates. The HSP90AB1 is a gene that plays important role in heat stress response. Scanning its allele and genotype variation could be beneficial for the selection of dairy cattle which able to cope with heat stress effect. This study aimed to identify HSP90AB1 gene polymorphism (SNP g.4338T $>$ C) in Indonesian local Friesian Holstein dairy cattle population. In total 20 cattle were sampled randomly. In this study, AS-PCR was employed to amplify $561 \mathrm{bp}$ of gene fragment, using pair of primer namely CF primer 5CTGGAGTCACACTGAGGAAC-3, TF primer 5-CTGGAGTCACA CTGAGGAAT-3, F primer 5-CTGGAGTCACACTGAG-3, and R primer 5-TGTTGGAGATCGTCACCTG-3. As the results, allele T and C were observed, and respective frequencies are 0.35 and 0.65 . Three genotypes of HSP90AB1 gene were found namely CC, CT, and TT. The respective genotype frequency is $0.1,0.5$, and 0.4. According to Hardy-Weinberg analysis, the population is in equilibrium $(\mathrm{P}>0.05)$. It is concluded that $\mathrm{CT}$ genotype and $\mathrm{T}$ allele are the highest frequency in the sampled population. Further study needs to be performed to associate the genotype and allele variation to productivity trait of local dairy cattle.
\end{abstract}

\section{Introduction}

The rising of global temperature, indicated by heat stress (HS), has been known to have serious impact directly and indirectly to livestock production. In dairy cattle industry, HS poses serious problems in reproductive performance [1,2], health [3], and milk yield productivity [4], which lead to huge economic loses [5]. Coping with HS condition becomes an underlined effort in dairy cattle that needs to be seriously underlined to maintain productivity [6]. Heat stress, biologically, impacts the response of animal body by change its

* Corresponding author: prastowo@staff.uns.ac.id 
metabolism [7]. Moreover, physiological change also impacted, such as heartbeat, respiration frequency, urination, feed consumption, more water consumption, and other related behavior. Those are the sign of heat stressed animal $[8,9]$. At the molecular level, HS change the expression of set of genes related to metabolism [10-13]. Animals started to suffer from HS at Temperature Humidity Index (THI) $>72$ [14].

Mammals react to HS with an evolutionarily old and conserved adaptive cellular system characterized by the transcriptional activation and accumulation of a set of proteins called heat shock proteins (HSP) [15]. These proteins have several isoforms that are categorized into families, based on their molecular weight, such as HSP27, HSP60, HSP70, HSP90, and HSP110/104 [16]. The 90 kilodaltons heat shock proteins (HSP90) act as important molecular chaperones which are constitutively expressed due to heat or stress induction [17]. Heat Shock Protein 90 Alpha Family Class B Member 1 (HSP90AB1) gene is a gene that plays a role in the body's physiological response to HS exposure. The HSP90AB1 gene is located in Bos taurus Autosome (BTA) 23, consists of 12 exons, gene ID 767874, and located at (NC_037350.1 (17752495...17758156) [18]. This gene contains SNP at position g.4338T> $\mathrm{C}$ with reference ID rs109251249 and has a significant effect on the heat-tolerant association trait as indicated by better physiological parameters of the body in heat-exposed cows such as lower respiratory rate, ability to maintain body temperature, and a high heat tolerance coefficient $[19,20]$. According to the previous studies this gene is reported to be associated with milk production traits [19,21].

Animals were exposed to HS when their surrounding environment was at THI $>72$ [14]. Indonesia has THI ranged from 73-82 [22], therefore it is demonstrated in previous study that when the dairy cattle were in heat stressed condition then it will impact on its thermoregulation and milk productivity [23]. Currently, there were no reports of HSP90AB1 gene variation and its association to productivity trait in local Friesian Holstein (LFH) dairy cattle. Therefore, this study aimed to know the genotype variation of HSP90AB1 gene polymorphism (SNP g.4338T $>$ C) in the LHF dairy cattle population, as molecular marker, which would be a steppingstone for the association study and further selection of HS resistance dairy cattle in Indonesia.

\section{Material and methods}

\subsection{DNA sample collection}

Twenty blood samples of LFH cows were randomly collected by venipuncture method from coccygeal vein using $21 \mathrm{GA} \times 1$ " BD Vacutainer ${ }^{\circledR}$ Flashback Blood Collection Needle (Becton, Dickinson USA). The vacutainer was attached to $5 \mathrm{ml}$ vacuum tube containing EDTA K3 (Onemed). Blood sample then homogenized and stored immediately at $4{ }^{\circ} \mathrm{C}$ temperature, following with transportation to the laboratory for DNA extraction.

\subsection{Genomic DNA extraction}

The genomic DNA was extracted using Wizard ${ }^{\circledR}$ Genomic DNA Purification Kit (Promega, USA). The extraction protocol was supplied by company and performed to the collected samples without any modification. Resulted DNA then stored in $-20^{\circ} \mathrm{C}$ until gene fragment amplification. 


\subsection{HSP9OAB1 gene fragment amplification and genotyping}

Amplification of HSP90AB1 gene fragment was done using allele specific polymerase chain reaction (AS-PCR) method using pair of primers as listed in Table 1. Each Forward (F) and Reverse (R) primer was used to amplify the HSP90AB1 gene fragment, meanwhile F-C and F-T primer were paired to $\mathrm{R}$ primer to amplify the specific alleles at SNP g.4338T> C (rs109251249) of the gene.

Table 1. Primer for PCR in HSP90AB1 gene

\begin{tabular}{|c|c|c|c|c|}
\hline & Primers & $\operatorname{Tm}\left({ }^{\circ} \mathrm{C}\right)$ & Product Size & Reference \\
\hline $\mathrm{F}$ & 5' CTGGAGTCACACTGAG 3' & \multirow{2}{*}{$58.9^{\circ} \mathrm{C}$} & \multirow{4}{*}{$561 \mathrm{bp}$} & \multirow{4}{*}{ [19] } \\
\hline $\mathrm{F}-\mathrm{C}$ & 5' CTGGAGTCACACTGAGGAA드 3' & & & \\
\hline F-T & 5' CTGGAGTCACACTGAGGAAT 3' & $57.9^{\circ} \mathrm{C}$ & & \\
\hline $\mathrm{R}$ & 5' TGTTGGAGATCGTCACCTG 3' & $58.9^{\circ} \mathrm{C}$ & & \\
\hline
\end{tabular}

Each PCR reaction was consisted of $10 \mu$ Promega Green PCR Master Mix (Promega, USA), $7 \mu$ nuclease-free water (Promega, USA), $1 \mu 1$ primer (Integrated DNA Technologies, Singapore) in each Forward and Reverse, and $1 \mu \mathrm{l}$ DNA template. The reaction was mixed in Axygen ${ }^{\circledR} 0.2 \mathrm{~mL}$ thin-wall 8 strips (Corning, USA) by gently vortex followed with 1 minute spin down. The PCR reaction was performed in SelectCycler ${ }^{\mathrm{TM}}$ II Thermal Cycler (SelectBioproduct, Taiwan) and set with initial denaturation step on $95^{\circ} \mathrm{C}$ for 5 minutes followed by 33 cycles of denaturation step on $95^{\circ} \mathrm{C}$ for 30 seconds, annealing step based on primer $\mathrm{Tm}$ (Table 1) for 30 seconds, extension step on $72^{\circ} \mathrm{C}$ for 30 seconds, and final extension on $72^{\circ} \mathrm{C}$ for 10 minutes. A negative control in every performed PCR reaction was always set by replacing the volume of DNA template with $1 \mu$ l nuclease-free water. To confirm the amplified DNA is part of HSP90AB1 gene, sample of PCR product amplified using F and R primer then sequenced by Sanger Sequencing Method.

To visualize the PCR product, electrophoresis reaction (100 V for 30 minutes) using Mupid-ExU (Mupid, Japan) on 2\% agarose stained with ethidium bromide was employed. The DNA bands then visualized under UV-transilluminator (Avegene, Taiwan). The allele then categorized as $\mathrm{C}$ type if DNA band is observed in PCR product resulted from the combination of F-C and R primer, while $\mathrm{T}$ type as the result of F-T and R primer. In this study, minimum two PCR reactions were performed in each DNA sample to determine the genotype of the cattle.

\subsection{HSP90AB1 gene polymorphism frequency analysis}

Allele and genotype frequency were analyzed according to the previous study [24]. Analysis of allele and genotype were described in formulas (1) and (2).

$$
x_{i}=\frac{2 n_{i i}+\sum n_{i j}}{2 N}
$$

Where: $x_{i}$ is allele frequency $\mathrm{i}, n_{i i}$ is the sum of genotype ii individual, $n_{i j}$ is the sum of heterozygote genotype ij, $N$ is total individual.

$$
x_{i i}=\frac{n_{i i}}{N}
$$

Where: $x_{i i}$ is genotype frequency ii, $n_{i i}$ is the sum of homozygote genotype ii, $N$ is total individual. 
The distribution of genotype in sampled population, to determine Hardy-Weinberg Equilibrium (HWE), was analyzed by chi-square test $\left(\chi^{2}\right)$ [24]. Following PCR product sequencing, the DNA sequence was then interpreted using Unipro UGENE software (http://ugene.net/) [25]. Subsequently, sequence was then aligned to sequence database using BLASTN on the NCBI website (https://blast.ncbi.nlm.nih.gov/Blast.cgi) [26].

\section{Results and discussion}

The HSP90AB1 gene fragment was successfully amplified (using $\mathrm{F}$ and $\mathrm{R}$ primer combination) resulting $561 \mathrm{~kb}$ of PCR product size (Figure 1), and there was no contamination occurred in this reaction confirmed by the absence of DNA band on negative control (NC) reaction. Simultaneously, the result of DNA sequence analysis confirmed that the amplicon is HSP90AB1 gene with $99.61 \%$ similarity (Table 2).

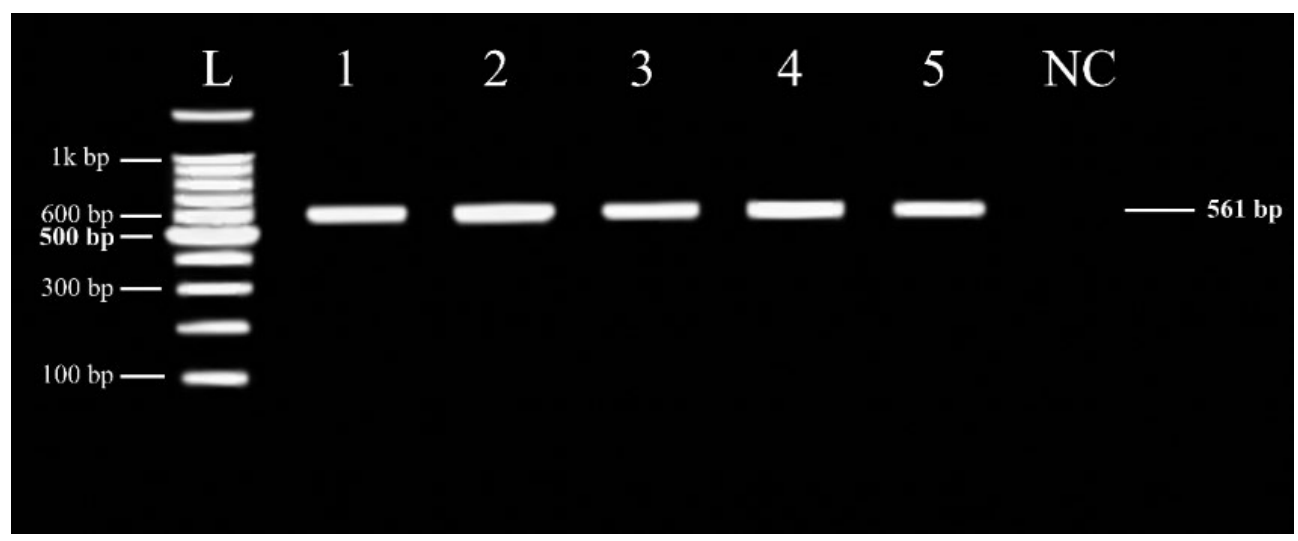

Fig. 1. PCR product visualization of HSP90AB1 gene. Note: (L) Ladder 100bp, (1-5) PCR Product, (NC) Negative Control

Table 2. The Similarity of amplified HSP90AB1 gene against reference sequence in NCBI database

\begin{tabular}{|c|c|c|}
\hline Sample ID & Similarity & Description \\
\hline \multirow{3}{*}{$\# 02$} & $99,61 \%$ & $\begin{array}{c}\text { Bos taurus heat shock protein 90 alpha family class B } \\
\text { member 1 (HSP90AB1), mRNA }\end{array}$ \\
\cline { 2 - 3 } & $99,23 \%$ & $\begin{array}{c}\text { Bos indicus partial HSP90AB1 gene for heat shock 90 kDa } \\
\text { protein 1, isolate WL }\end{array}$ \\
\hline
\end{tabular}

The AS-PCR of HSP90AB1 gene in LFH population revealed two alleles (C and T) and three genotypes (CC, CT and TT). The CC genotype was shown by the present of band in $1^{\mathrm{c}}$ well only because only C-specific primers pair could be amplified, otherwise TT genotype was shown by band in $2^{\mathrm{T}}$ well because only $\mathrm{T}$-specific primers pair could be amplified. Moreover, CT genotype was consisting of the present of band in $3^{\mathrm{C}}$ and $3^{\mathrm{T}}$ well because the successful amplification of both $\mathrm{C}$ and $\mathrm{T}$ allele using specific primers pair (Figure 2). ASPCR method had advantages in genotyping analysis that are low cost and easy to use. This because the amount of equipment used is relatively small and easy for the discriminant process in genotyping, and the destabilizing mismatch in 3' of allele specific primers could be increase the specificity of reaction [27] 


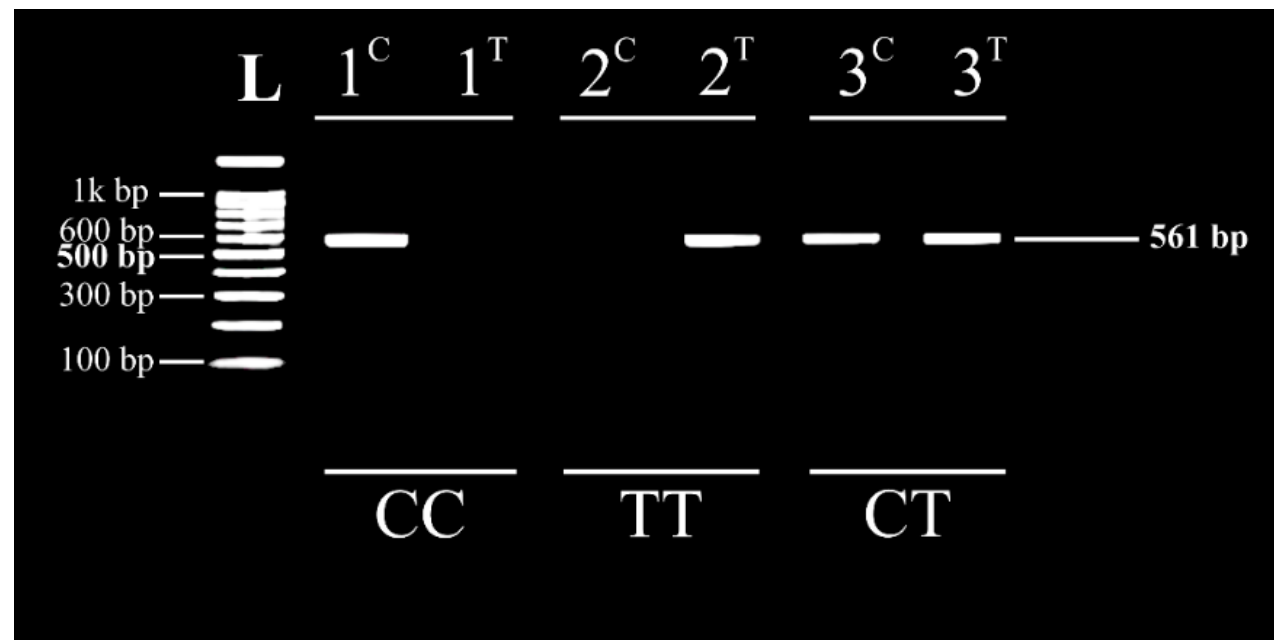

Fig. 2. Visualization of AS-PCR of HSP90AB1 genotype. Note: (L): Ladder $100 \mathrm{bp},\left(1^{\mathrm{C}} 1^{\mathrm{T}}-3^{\mathrm{C}} 3^{\mathrm{T}}\right)$ HSP90AB1 gene AS PCR product, (CC, TT, CT): genotype

The allele and genotype frequencies analysis show $0.25,0.75$ in $\mathrm{T}, \mathrm{C}$ allele, and 0.10 , $0.40,0.50$ in CC, TT, CT genotype respectively (Table 3 ). The highest allele and genotype in LFH population was $\mathrm{C}$ allele and CT genotype, while the lowest was $\mathrm{T}$ allele and CC genotype. In the sampled population, according to HWE analysis shows that the LFH population is in equilibrium $(\mathrm{P}<0.05)$.

Table 3. Genotype and Allele Frequency of HSP90AB1 Gene in local FH Population

\begin{tabular}{|c|c|c|c|c|c|c|c|}
\hline \multirow{2}{*}{$\mathbf{N}$} & \multicolumn{3}{|c|}{ Allele } & \multicolumn{3}{c|}{ Genotype } & \multicolumn{2}{c|}{ HWE Analysis } \\
\cline { 2 - 8 } & $\mathbf{C}$ & $\mathbf{T}$ & CC & CT & TT & $\chi^{2}$ & P-Value \\
\hline 20 & 0.75 & 0.25 & 0.10 & 0.50 & 0.40 & 0.0098 & 0.99 \\
\hline
\end{tabular}

The polymorphism of HSP90AB1 SNP g.4338T $>$ C (rs109251249) at T allele was reported more tolerance to heat, indicated by better respiration rate and rectal temperature, in Thailand indigenous cattle when compared to Holstein [15]. That report was in accordance with the result showed that TT genotype is significantly associated with high heat tolerance coefficient and low average respiration rate than CT and CC genotype in Indian dairy cattle breed [19]. Other report which using HSP90AB1 gene but different polymorphism site at intron $10(\mathrm{C} 17872061 \mathrm{~T})$, reveal that $\mathrm{CT}$ genotype has higher milk production but low respiration rate and rectal temperature compared to CC genotype in Sahiwal cows [21]. Moreover, in Jersey cattle the polymorphism of HSP90AB1 shows that CC genotype at T17872112C locus significantly has lower respiration rate than TT and TC genotypes [28]. From those studies, we can assume that HS effects to respiration rate, rectal temperature, heat tolerance coefficient, and finally to milk production. However, at difference breed shows difference genotypes which significantly associated with the better response of physiological condition and milk yielded. Since HSP play a crucial role in cellular thermotolerance and HS response [19], hence the identification of gene variation of responsible protein could be an option to select better animal response to HS though HSP90AB1 is not causative for the physiological response. Though it's not directly related, but then HSP90AB1 can be proposed as molecular marker to select appropriate breed for hot climate [15].

In overcome HS effect, many strategies had been done and/or proposed ranged from nutrient manipulation, housing management, and genetic selection. However, the final goal of these efforts is to minimize the HS effect while maintain the animal productivity [29]. 
Indonesia as tropical country, indicated by high temperature and humidity level, HS became a major influence in maintaining the dairy cattle productivity. The majority breed for dairy in Indonesia is Friesian Holstein which selected and imported from both Australia and New Zealand to establish cattle breeding stock [30]. The climate differences between its origin and in Indonesia resulting different milk production capacity as demonstrated in previous study [31,32], and HS is pointed to be the root of problem [22]. Of that, in Indonesian cases, the use of HSP90AB1 polymorphism may be one of aid in selection and breeding program to enhance thermo-tolerance in dairy cattle.

\section{Conclusion}

The allele and genotype variation of HSP90AB1 gene in the studied population were $\mathrm{C}, \mathrm{T}$ allele and CC, CT, TT genotype. In this study we found T allele and CT genotype are the highest frequency observed. Further study needs to be performed to associate the allele and genotype variation of HSP90AB1 to the cattle physiological parameters and productivity trait which impacted by HS in LHF population. Once association study gives result, animal(s) which carry alleles or genotypes resistance to HS could be selected and multiplied in planned dairy cattle breeding program.

The LFH cattle DNA analyzed in this study were collected by Sigit Prastowo (Universitas Sebelas Maret) and Purwadi (Universitas Boyolali) in Boyolali area as part of research project with tittle "The variation analysis of Bovine Follicle Stimulating Hormone Receptor (FSHR) and its association to Indonesian Holstein Reproductive Performance". The project was coordinated and administrated by Sigit Prastowo.

\section{References}

1. S. Dash, A.K. Chakravarty, A. Singh, A. Upadhyay, M. Singh, and S. Yousuf, Vet. World 9, 235 (2016).

2. I. Ahmad Para, P. Ahmad Dar, B. Ahmad Malla, M. Punetha, A. Rautela, I. Maqbool, A. Mohd, M. Ahmad Shah, Z. Ahmad War, R. Ishaaq, W. Akram Malla, A. Ahmad Sheikh, and M. Rayees, Biol. Rhythm Res. 51, 616 (2020).

3. M.R.H. Rakib, M. Zhou, S. Xu, Y. Liu, M. Asfandyar Khan, B. Han, and J. Gao, J. Dairy Res. 87, 315 (2020).

4. P. Pragna, P.R. Archana, J. Aleena, V. Sejian, G. Krishnan, M. Bagath, A. Manimaran, V. Beena, E.K. Kurien, G. Varma, and R. Bhatta, Int. J. Dairy Sci. 12, 1 (2017).

5. M. Mondaca, F. Rojano, C.Y. Choi, and K.G. Gebremedhin, Trans. ASABE 56, 1471 (2013).

6. A. Sammad, Y.J. Wang, S. Umer, H. Lirong, I. Khan, A. Khan, B. Ahmad, and Y. Wang, Animals 10, (2020).

7. P.A. Gonzalez-Rivas, S.S. Chauhan, M. Ha, N. Fegan, F.R. Dunshea, and R.D. Warner, Meat Sci. 162, (2020).

8. M. Al-Qaisi, E.A. Horst, S.K. Kvidera, C.S. McCarthy, E.J. Mayorga, M.A. Abeyta, B. Goetz, N.C. Upah, D.M. McKilligan, B.W. Kolstad, L.L. Timms, and L.H. Baumgard, Res. Vet. Sci. 132, 42 (2020).

9. J.B. Wheelock, R.P. Rhoads, M.J. VanBaale, S.R. Sanders, and L.H. Baumgard, J. Dairy Sci. 93, 644 (2010).

10. A. Sigdel, R. Abdollahi-Arpanahi, I. Aguilar, and F. Peñagaricano, Front. Genet. 10, (2019). 
11. G.S. Sengar, R. Deb, U. Singh, T. V. Raja, R. Kant, B. Sajjanar, R. Alex, R.R. Alyethodi, A. Kumar, S. Kumar, R. Singh, S.J. Jakhesara, and C.G. Joshi, Cell Stress Chaperones 23, 155 (2018).

12. H. Luo, X. Li, L. Hu, W. Xu, Q. Chu, A. Liu, G. Guo, L. Liu, L.F. Brito, and Y. Wang, J. Dairy Sci. 104, 4441 (2021).

13. Z. Abbas, A. Sammad, L. Hu, H. Fang, Q. Xu, and Y. Wang, Metabolites 10, 1 (2020).

14. L. Polsky and M.A.G. von Keyserlingk, J. Dairy Sci. 100, 8645 (2017).

15. R. Charoensook, K. Gatphayak, A.R. Sharifi, C. Chaisongkram, B. Brenig, and C. Knorr, Trop. Anim. Health Prod. 44, 921 (2012).

16. K.C. Kregel, J. Appl. Physiol. 92, 2177 (2002).

17. B. Chen, D. Zhong, and A. Monteiro, BMC Genomics 7, 1 (2006).

18. N.A. O'Leary, M.W. Wright, J.R. Brister, S. Ciufo, D. Haddad, R. McVeigh, B. Rajput, B. Robbertse, B. Smith-White, D. Ako-Adjei, A. Astashyn, A. Badretdin, Y. Bao, O. Blinkova, V. Brover, V. Chetvernin, J. Choi, E. Cox, O. Ermolaeva, C.M. Farrell, T. Goldfarb, T. Gupta, D. Haft, E. Hatcher, W. Hlavina, V.S. Joardar, V.K. Kodali, W. Li, D. Maglott, P. Masterson, K.M. McGarvey, M.R. Murphy, K. O’Neill, S. Pujar, S.H. Rangwala, D. Rausch, L.D. Riddick, C. Schoch, A. Shkeda, S.S. Storz, H. Sun, F. Thibaud-Nissen, I. Tolstoy, R.E. Tully, A.R. Vatsan, C. Wallin, D. Webb, W. Wu, M.J. Landrum, A. Kimchi, T. Tatusova, M. DiCuccio, P. Kitts, T.D. Murphy, and K.D. Pruitt, Nucleic Acids Res. 44, D733 (2016).

19. S.E. Hunt, W. McLaren, L. Gil, A. Thormann, H. Schuilenburg, D. Sheppard, A. Parton, I.M. Armean, S.J. Trevanion, P. Flicek, and F. Cunningham, Database (Oxford). 2018, 1 (2018).

20. B. Sajjanar, R. Deb, U. Singh, S. Kumar, M. Brahmane, A. Nirmale, S.K. Bal, and P.S. Minhas, Anim. Biotechnol. 26, 45 (2015).

21. S. Lalrengpuii, D.G. I, V. Archana, D. Ramendra, and V.C. M, African J. Biochem. Res. 9, 99 (2015).

22. P. Sudrajad and Adiarto, Semin. Nas. Teknol. Peternak. Dan Vet. Bogor, 7-8 June 2011. Bogor Puslitbang Peternakan, 2012. 341 (2011).

23. E. Mariana, C. Sumantri, D.A. Astuti, A. Anggraeni, and A. Gunawan, Bul. Peternak. 43, (2019).

24. M. Nei and S. Kumar, Molecular Evolution and Phylogenetics (Oxford University Press, New York, 2000).

25. K. Okonechnikov, O. Golosova, and M. Fursov, Bioinformatics 28, 1166 (2012).

26. G.M. Boratyn, C. Camacho, P.S. Cooper, G. Coulouris, A. Fong, N. Ma, T.L. Madden, W.T. Matten, S.D. Mcginnis, Y. Merezhuk, Y. Raytselis, E.W. Sayers, T. Tao, J. Ye, and I. Zaretskaya, Nucleic Acid Res. 41, 29 (2013).

27. M. Gaudet, A.-G. Fara, I. Beritognolo, and M. Sabatti, in Single Nucleotide Polymorphisms. Methods Mol. Biol. (Methods Protoc. , Vol 578, edited by A.A. Komar (Humana Press, Totowa, NJ, 2009), pp. 415-424.

28. L. Sailo, I.D. Gupta, A. Verma, A. Singh, M.V. Chaudhari, R. Das, R.C. Upadhyay, and J. Goswami, Anim. Sci. Report. 9, 43 (2015).

29. T. Saizi, M. Mpayipheli, and P.A. Idowu, J. Anim. Behav. Biometeorol. 7, 39 (2019).

30. M. Pangestu, Y. Subagyo, P. Yuwonol, and B. Rustomo, Asian-Australasian J. Anim. Sci. 13, 505 (2000).

31. S. Prastowo, T. Nugroho, N. Mahfudhoh, F.Y. Putra, Subiakti, A. Ratriyanto, A. Susilowati, Sutarno, and N. Widyas, IOP Conf. Ser. Mater. Sci. Eng. 633, 12021 (2019).

32. N. Widyas, N. Mahfudhoh, Subiakti, and S. Prastowo, AIP Conf. Proc. 2202, 1 (2019). 